\title{
Research on the Development of Teaching Academic Ability of English Teachers in Local Universities
}

\author{
Zhou Yun \\ School of Foreign Languages, Yuxi Normal University, Yuxi, Yunnan 653100 \\ hunter2011@foxmail.com
}

Keywords: local universities, English teachers, Teaching academic ability, The development strategies.

\begin{abstract}
The value of teaching academy of teachers in universities lies in expanding the academic scope, encouraging teachers to have a rational understanding of teaching activities in universities, making teachers do reflection and researches about the teaching, enriching teachers theoretical basis of teaching. It is also helpful to promote teachers' professionalism and improve their quality, guide their teaching activities, making sure that the teaching tasks can be finished. As an English teacher, the author does systematic analysis mainly from the learning level and that of teachers themselves, and puts forward strategies, based on the author's years' working experience, to the development of teaching academic ability of English teachers in local universities.
\end{abstract}

\section{At the School Level}

Improving the understanding of the importance of teaching academy. Universities and leaders of universities should fully realize the academy of the teaching and the significant role the teaching plays in academic activities in universities, and put the task of promoting the teaching academy of teachers in universities in the first place. They should treat the teaching as an academic career, guild and encourage teachers to conduct researches on the teaching actively and improve the teaching academy. Universities should abandon wrong and one-sided understanding of teaching academy, eliminate the prejudice that only science is academy, realize that the teaching of high quality is also an academic activity and measure the teaching with the academic standard. Universities should actively promote the academic philosophy of the teaching, mobilize teachers their enthusiasm of the teaching and researches of it and encourage teachers to do researches and to develop their teaching academy. Universities also should work hard to improve the position of the teaching and the teaching academy, coordinate and handle the relationship between the teaching and researches, making it every teacher's academic responsibility to develop the teaching academy. Universities should take the initiative to create a teaching academic atmosphere, formulate the plan of the development of the teaching academy and respect as well as encourage teachers who make contributions to the improvement of the teaching academy.

Developing effective systems to encourage teachers to upgrade their academic level of the teaching. With the establishment of market economy system, the connection between universities and communities becomes more and more close, making researches in universities more and more utilitarian. With money and interest oriented, some teachers "conduct researches" in order to "conduct researches", which leads them to pay less attention to the teaching and researches on the teaching, resulting in their low level of the teaching academy. Therefore, universities and administrators of universities have the responsibility and obligation to formulate regulations to encourage teachers to study the teaching and improve the teaching academy, forming the incentive system of the teaching academy, which inspires teachers to develop the teaching academy actively, makes every teachers become passionate about the teaching and research work and clear about the value of the teaching academy, and has the regulations which encourage teachers to improve teaching academy implemented. Moreover, universities should continue to improve the teaching and the academic evaluation system, carefully think about the reasons and the way to evaluate the teaching, making the aim, the standard and the content of the evaluation clear, the teaching academy 
of teachers truly improved. So, in order to change the status of the teaching academy of university teachers, universities must formulate effective regulations encourage teachers to improve their teaching academic level.

Carrying out training activities to improve the teaching academic level of teachers. First is to build the pre-teaching educational system. Nowadays, postgraduate education in comprehensive universities answers for the teacher training of higher education in China, among which that in research universities plays a main part in training new teachers in universities to a large extent. Therefore, these universities should offer courses of basic educational theories to those who choose to be university teachers (these comprehensive courses include educational philosophy, educational process, educational psychology and so on), and give them opportunities to take internship to conduct corresponding researches on teaching theories and explore the practice of the teaching.

Second is to build the pre-teaching training system. The training the university teachers receive before they begin to work is for every new teacher, which is an important step for new teachers to transit from pre-work learners to vocational educators as well as to change their career awareness. Through pre-work training, new teachers can experience various responsibilities of teachers, and can exchange as well as discuss their ideas about the roles teachers play.

Third is to build in-service training mechanism for university teachers. The forms of in-service training for university teachers should be various, which can be implemented in forms of being visit scholars, short and long term training study abroad and visit the school, establishing teaching guidance organization of universities and teaching supervision and so on. Universities can also integrate a variety of ways to implement this mechanism, but they should especially pay attention to the teaching supervision work. Visits and exchanges between university teachers should also be increased.

\section{At the teacher level}

Strengthening the awareness of improving the teaching academy. The understanding of university teachers to the teaching and the teaching academy directly impacts and restricts the quality of the teaching and the teaching academic level of teachers. Although their duty is teaching, teachers usually think that "mastering professional knowledge of their disciplines is equivalent to know how to teach." Teachers seldom regard the teaching as one of their own expertise, let alone doing researches on it. This one-sided view of the teachers is undoubtedly not conducive to developing their teaching expertise and improving their teaching level. Therefore, teachers should pay attention to the teaching, regard cultivating students as their own responsibilities, and make themselves happy about the teaching when realizing that "the teaching level is also academic level, which is not an optional adjunct but the core of teachers' careers". Teachers should understand that the teaching is an important part in their academic life, and study and develop their teaching academy is a must for them to perform their primary academic responsibility and also the basic condition to do well in the teaching, so it is important to strengthen the awareness of study and develop the teaching academy. Only by truly strengthen the awareness of improving the teaching academy can teachers be inspired to study and develop the teaching academy and can they improve their teaching quality and implement the teaching tasks.

Learning and mastering knowledge of the teaching. University teachers should strengthen their awareness of the teaching academy, and at the same time, they should also continue to learn and master knowledge and ways related with the teaching in order to constantly improve their teaching academic level. Teachers with high teaching academic level should have a solid professional knowledge and rich educational theory and extensive knowledge of related disciplines, and constantly expand and enrich their knowledge in the teaching practice.

Firstly, learning and mastering professional knowledge of disciplines they teach. As scholars and researchers in the professional fields, university teachers should strive to explore the history and current status of disciplines they teach, grasp the professional trends and research tendencies, make sure that "no matter what discipline students choose, teachers can let them understand the primary construction of the subject", leading students enter the frontier areas of the subject in the case of 
reinforcing students' theoretical foundation. However, to reach that point, teachers should have a unique insight into the knowledge of disciplines they teach and also can flexibly use it, and have solid basic skills in their disciplines. "Rome wasn't built in a day." Unremitting accumulation and summary as well as constant learning make teachers' professional theories rich.

Secondly, teachers should learn and master the knowledge in the educational subjects, and study theories of educational teaching. Teachers should "teaching knowledge and cultivate people". In addition to master the profound professional knowledge, teachers should also arm themselves with the knowledge of education, psychology and pedagogy. To learn the knowledge of education and pedagogy, teachers should pay attention to learn the general knowledge of education and the content of pedagogy. University teachers should be not only experts in disciplines they teach, but also educators, which requires that university teachers not only need to have a high academic level but also acquire some certain educational theories, and understand and grasp the characteristics as well as laws of the teaching process, teaching principles, teaching methods and psychological characteristics of students, etc. Teachers must constantly learn and explore pedagogy, psychology and so on, and continue to explore and summarize practical teaching methods and teaching experience. Teachers can look for teaching laws and common properties through the study, analysis and criticism, and give their service to researches on the teaching theories and teaching practice, just as the old saying goes "keep the essence, goes the dregs".

Thirdly, teachers should learn and master knowledge of corresponding disciplines. A wide range of relevant knowledge is a useful supplement to professional knowledge of the discipline and is helpful to carry out the teaching activities and improve the academic level, which can not be ignored. The net structure of connecting professional knowledge and the relevant knowledge together can help teachers establish a comprehensive system of knowledge, which broads teachers' thought and vision and improve their comprehensive ability. With modern technologies advancing, systems of knowledge fast updating, many concepts and knowledge of students are often built based on subjects that relating to each other. So only teachers are "conversant with ancient and modern learning" can they help students build a rational structure of knowledge. These relevant disciplines generally involve literature, philosophy, history, logic, ethics, aesthetics and systematic science and so on.

Cultivating teaching abilities. First, teachers should have the ability to control classes. As the main channel for the dissemination of knowledge and the basic organizational form of teaching, the effect of the classroom teaching has a direct influence on the quality of the teaching. Teachers' ability to have a good control over the class is the key for them to complete teaching tasks, achieve teaching goals and improve teaching quality. Teachers can adopt various kinds of forms to do classroom teaching, and resort to other teaching forms besides the traditional lectures when dealing with different teaching content and distinct students, such as problem-solving, discussion style, experimental discovery, etc. Based on the specific characteristics and the actual situations of classes, teachers can make best use of their advantages and bypass their disadvantages and control classes freely.

Secondly, teachers should have the ability of organizing their language. For teachers, the ability of language organization and expression is an important guarantee of improving the effectiveness of the classroom teaching. In the teaching process, teachers' teaching language should be featured: First, the teaching language is the one with a scientific nature. The main task of classroom teaching is to teach students the systematic scientific knowledge, so the teaching language must be scientific, concise, orderly and logical. Secondly, the language must be instructive. Whether the teaching language is instructive or not is highly correlated to whether teachers can expand students' thinking, lead students to think actively and make students take the initiative to acquire knowledge. Finally, the teaching language should be vivid. Teachers should be good at using vivid language, to stimulate students' creative thinking and imagination. The vivid language of teachers can cause students' attention and enhance their intellectual curiosity.

Thirdly, teachers should have the ability to know how to use the textbook. To know how to use the textbook systematically, teachers should first of all study the textbook comprehensively based 
on the teaching theory, forming a regular system about concepts, definitions, principles and rules of the course. Teachers should study the design thought of the textbook, master the logical structure of the textbook carefully and make a teaching program scientifically based on a macroscopic and systematic research, which can ensure that teachers have a general idea about teaching.

Fourthly, teachers should have the skills of interpersonal communication. Teachers should constantly observe and understand students 'mental activities meet their psychological aspirations and needs, establish a close relationship with students and help to solve their difficult problems. Teachers need to have enough patience to communicate with those students who are resisting to study. Therefore, good communication skills between teachers and their colleagues and students are important guarantee for the smooth development of teaching.

Fifth, teachers should have the ability to reflect teaching. The ability to reflect the teaching is an important guarantee for teachers to improve their teaching quality, promote their teaching academy. Famous American educational psychologist Posner believes that "Experience + Reflection $=$ teachers' growth." University teachers should be "reflective practitioner". Through reflection on the teaching activities, teachers can improve their teaching, adopt teaching intervention and enhance their teaching practical abilities. Therefore, university teachers not only have the mission of "preaching, teaching, questions-solving", but also should pay attention to reflect the teaching and become good at teaching reflection.

Conducting teaching researche. If university teachers want to develop the teaching academy, improve their teaching levels and improve the quality of the teaching, they must actively carry out teaching researches. The process of teaching researches is the one the teacher should constantly explore, integration and application of the teaching knowledge, and it is also the one during which teachers continue to enrich and improve their teaching theories. Teachers should not only teach, but also know how to teach, which means that teachers must study the teaching. First, individual teachers should learn and study the teaching. The aim of teachers to study the teaching is to reveal the rules of the teaching and guide the teaching practice. In the teaching process, teachers should make judgment and reflection on a variety of teaching phenomena, and then make a rational analysis and summary. By self-study, teachers should cultivate the ability of finding, analyzing and solving problems independently, which helps them to have a good control about the teaching process and improve their teaching level.

Making exploration of the teaching. University teachers should carry out theoretical studies, and at the same time, they must actively explore teaching practice. In order to acquire knowledge, students enter universities, making it the basic task for teachers to teach students knowledge and cultivate their abilities and develop their characters. It is a must for teachers to think when exploring the teaching practice about how to meet the different learning needs of students, how to teach students the way to learn and how to effectively improve the quality of the teaching. On the one hand, teachers should draw and summarize the rich experience left by their predecessors, connect the teaching theory and the teaching practice organically to achieve the unity. On the other hand, teachers should have the courage to make innovations and breakthroughs in the teaching practice, reform the teaching with the premise of following laws of the teaching, and constantly improve their teaching level and academic level. The formation of the teaching academy involves teachers' reflection on the knowledge of the teaching based on their researches and experience, whose key lies in applying the educational theories and researches to the teaching practices effectively.

\section{References}

[1] L.G. Zhou, Ma Haiquan. The Teaching Academic Ability: the New Fragment of the Development and Estimation of University Teachers. Educational Research, 2013, 08: 37-47.

[2] Y.R. Zhou, Y.M. Li. Structure and Assessment of University Teachers' Teaching Academic Ability. The Higher Education's Development and Assessment. 
[3] H. Chen, P. Zhou. Teaching Academic Ability: the Rational Appeal of the Teaching Development of Young Teachers. Education Exploration, 2015, 04: 124-126.

[4] L.J. Dai. Teaching Development Centre: An Operational Mechanism to Promote the Development of the Teaching Academic Ability. Higher Education in Coal Industry,2013. 06:56-59.

[5] H. Yin. The Status of University Teachers' Teaching Academy and Strategies to Improve It. Hunan University,2008.

[6]S.S. Qi. The Analysis on the Teaching Academy of University Teachers. Hunan University,2005. 